\title{
Multiple Contracts According to the Fatwa of National Sharia Council
}

\author{
Bukhoree Lateh ${ }^{1}$ \\ ${ }^{1}$ Ma'had Al-Muhammadi High School, Pattani, Thailand. \\ Email: rawahu_333@hotmail.co.th
}

\begin{abstract}
:
At the recent decades, the business activity in Islamic Financial Institutions consists of funding, financing, and service. These are addressed to economic development and improving the society welfare. In the line of funding, the people can invest their money such saving and deposit. Uniquely, deposits may be withdrawn at any time with the use of checks, gyro, forms of payment order, or money transfer. But, not all gyro transactions can be justified by Islamic law (Sharia) in which uses the principle of sharia mutual benefit. Therefore, the National Sharia Council National Sharia Council of Indonesian Council of Ulama (NSC-ICU) deems it necessary to be set in the Fatwa mu'ā mala form that can be used as the guidelines for the implementation of current accounts in Sharia Banking Institution. It is referring to the National Sharia Board Fatwa DSN-MUI Number: 01/DSNMUI/IV/2000). Based on the reason, this paper will explain the Implementation of Multiple Contract (al-'uqū d al-murakkaba) according to the fatwa of National Sharia Council.
\end{abstract}

Keywords: Multiple Contract (al-'uqū d al-murakkaba), Hịllah (legal fiction), Fatwā.

\section{A. INTRODUCTION}

Many of the contract that has been discussed and practiced during the previous scholars cannot fully practiced in the present. The development of the transaction model is especially true of the parties involved ('à qid) and the means of delivering the contract (șighah). The contracting parties in the Islamic financial institutions may be more than two, and in the discussion of jurisprudence generally two parties. Means of delivery and granted consent to use information technology that enables not meet directly between parties to a contract is commonly practiced. In response to the needs of modern transactions, jurists and institutions fatwa perform contract development and establish additional requirements. The development contract in question as a result of the adjustment effort Jurisprudence conducted fatwa authority on modern financial products. Among the forms of contract is an innovation development contract (make a new contract) and the modification of the contract. Innovation means creating a contract agreement that did not previously exist. Modification of the contract means creating a new form of contract with contract-modifying an existing contract. Most forms of contract modifications have been also discussed by classical scholars, such as multiple contract. Such practices have occurred even during the Prophet Muhammad's life, as quoted from the sayings on the prohibition of the merger of several contracts in one transaction.

The development of Islamic banking and finance is progressing very rapidly and facing the challenges of an increasingly complex (Meftah, 2013). Banking and Islamic financial institutions 
must be able to meet the needs of modern business by providing innovative products and more varied and satisfying service. This challenge demands the practitioners, regulators, consultants, and academics sharia council of Islamic financial field to always be active and creative in responding to these developments. Practitioners are required to creatively innovate products, regulators to make regulations that regulate and supervise the products carried by the practitioners, the Board of sharia prosecuted actively and creatively issue fatwas industry needs as demanded by the times, and academics was prosecuted provide scientific enlightenment and guidance in order products and regulations support the needs of modern and really did not deviate from the principles of sharia.

\section{B. METHODS}

There is a strong relationship between product innovation with market development of Islamic banks. This means that the more innovative Islamic bank to make the product, the faster growing markets. So weak product innovation Islamic banks, however, will impact significantly to the slow development of the market. Weak product innovation and market development of Islamic banks must be overcome, in order to accelerate the development of Islamic banks more quickly. Product innovation is required in order that Islamic banks can be optimized in the face of a global phenomenon. Because it must take the initiative in market development and product development.

Therefore, as academics whose job is to give scientific explanations and guidance to product innovation of Islamic financial institutions in order to sharia-compliant, then in this article will be discussed on the Application of Hybrid Concept Product Contracts in the Giro, using survey methods literature.

\section{RESULT AND DISCUSSIONS}

\section{The Emergence of Multiple Contract}

Multiple contract can be divided into five types: conditional-contract (al-'uqū d al-mutaqā bila), accumulated contract (al-'uqū d al-mujtami'a), opposite contract (al-'uqū d al-mutanā qiḍa wa almutaḍaḍa wa al-mutanā fiya), different contract (al-'uqū d al-mukhtalifa) and similar-contract (al'uqū d al-mutajā nisa). Of the five types, only conditional-contract (al-'uqū $d$ al-mutaqā bila) and accumulated contract (al-'uqū $d$ al-mujtami'a) which are commonly used in the use of multiple contract. (Hasanuddin, 2008: 53)

The definition of conditional contract in the form of multiple contract is the first contract responds to the second, in which the fulfillment of the first contract depends on the fulfillment of the second contract, through a reciprocal process. In other words, the contract dependent on the other contract. In the tradition of jurisprudence, the agreement model like this has been long known and have a lot of practice. Many scholars have discussed this theme, both with regard to its legal, or exchange models; for example, exchange contract (mu'ā waḍa) with tabarru contract. Scholars define this contract with a conditional agreement (ishtirat 'aqd bi 'aqd). While accumulated contract (al-'uqū $d$ al-mujtami'a) is a multi-contract collected in a single contract. Multiple contract that is could happen with gathering together the two covenants have different legal effect in the contract of the two objects at one price, two different contract law in the contract due to two objects with two prices, or two contract within a contract different laws on one object with the rewards, both in the same time or at different times. 


\section{The legal status of multiple contract}

The legal status of multiple contract not necessarily equal to the legal status of contracts that build it. As an example, the prohibition of bay' and salaf contracts are clearly stated by the Prophet. But if the second contract that stand on their own, then either contract (bay' and salaf) allowed. That is, the multiple contract law cannot be solely seen from a legal-contract agreement that build it. It could be contract-build contract that is allowed when standing alone, but it becomes unlawful when the agreement-contract was assembled in a single transaction. It can be concluded that the law of the multiple contract not necessarily the same as the law of contracts that build it.

Although there are multiple contract that is forbidden, but the principle of them are allowed and the law of multiple contract analogized with contract law that is built. This means that every mu'à mala that is assembled the contract, is lawful as long as all of that is build contract is allowed. This provision gives the opportunity on the manufacture of models containing multi-contract transactions. Indeed, there are some schools of Al-Zahiri scholars, including Ibn Hazm who argue that all contracts and terms are invalid, unless allowed by the texts and consensus. However, this opinion was considered narrower and less in accordance with the spirit of the teachings of Islam. (Praja, 2012: 118).

The permissibility of multiple contract must pay attention to provisions that is restrict religion. That is, although the multiple contract is allowed, there are boundaries that is should not be violated, because of the restrictions it becomes a sign for multiple contract in order not to fall to the mu'ā mala practices that are forbidden.

Multiple contract is a new breakthrough in modern business, although at the time of the Prophet it has happened. Proved the existence of the Prophet's hadith that prohibits the practice of multiple contract which is not in accordance with Islamic law. In the modern business activities, transactions using multiple contract diverse and varied, and most of the people in need of this transaction, as in modern trade transactions, banking, financial markets and so forth.

There are several reasons and the emergence of multiple contract practice, namely:

a. Hïlah (Legal fiction) of law and avoid practices that are forbidden, so this hillah means to justify a particular transaction. Transactions containing jahā lah and usury which has clearly forbidden by the Shari'a. By doing Hilah, such a transaction as if it is allowed.

b. Hillah (Legal fiction) administration, by collecting two or more of the contract in order to escape from having to pay a certain assurance, tax, compensation, and so on.

c. Hīlah (Legal fiction) for creating a legal solution (makhraj shar'i) to avoid prohibited transaction.

d. Hīlah (Legal fiction) for engineering price through multiple-contract order to obtain large profits or minimize losses.

e. Hịlah (Legal fiction) for obtaining (loan) money.

f. Hīlah (Legal fiction) for reducing risk and providing a guaranteed capital or part of the capital.

g. Hīlah (Legal fiction) for Promotion and marketing of products. Through the "network" transactions so unloved products sold for its links to other products, while the other product that is preferred; or otherwise, of purchasing the first product as the only way to get the desired product.

h. Hīlah (Legal fiction) for making a guaranteed purchase of products by customers.

i. Hīlah (Legal fiction) for simplifying the load. 
If observed, the causes of multiple contract above divided into two categories; justified by law and prohibited. Legal fiction (Hilah) to avoid something forbidden is forbidden. However, the examples of sharia compliant alternative solutions (makhraj shar'i) is an example of a justifiable reason.

Subhi Mahmashani confirms that fact in qardh (loan) no reward. Therefore every action $H$ illah (legal fiction) to get the rewards do not match with sharia is prohibited, such Bay' 'Inah. While Hilah allowed is which do not violate the law. For example, muqrid lend to muqtarid, then muqtarid sell goods to muqrid at lower prices, or muqriḍ sell goods to muqtarid at higher prices. Hīlah therefore justified by the Hanafiya and partly Shafi'ites. (Hasanuddin, 2008: 222)

\section{Hadith Based Multiple Contract}

In the hadith of the Prophet clearly stated three forms of multiple contract prohibited: (1) the multiple contract in buying, selling and borrowing; (2) in the sale and purchase agreement; and (3) the two transactions in one transaction.

The Prophet forbade two sales in a single transaction, and from selling to lend, and of the advantages of the goods cannot be guaranteed, and of selling which had not with you (Ahmad: 1414 H).

Based on the critical analysis, the hadith can be categorized into hadeeth șahīh, because of seen from the quality of narrators which narrated the hadith, no one of them has a cause of rejection the story conveys. In addition, the hadith is also reinforced by different narrators, including in Abu Dawud, Nasa'i, Tirmidzi. So that it becomes a famous hadith.

A contract was valid for the object and the price is known by both parties. If one of them is not clear, then the law of the contract is prohibited. Prohibition of collecting Salaf by buying and selling in the contract to avoid falling prey to usury is forbidden. It happened because someone lent a thousand, then sell the goods at a price of eight hundred thousand. Thus, he has provided goods worth a thousand and eight hundred to get paid two thousand. Here he gained excess of two hundred and it is usury.

Based on the Hadith, the scholars agreed to prohibit multiple contract between the sale and purchase and qard in one transaction. All contract that contains elements of buying and selling is forbidden to compiled with qarḍ in one transaction, such as the ijā ra with qarḍ, greeting qard, sharf with qard and others.

Regarding the ban on buying and selling two in a single purchase, many opinions of the scholars that is scattered about the purpose of buying and selling the two in a single purchase. The opinions the most robust in this regard is the notion that the contract price and thus make it less obvious plunges into usury. This opinion interprets that someone is selling something to be paid in installment, on condition that the buyer must sell it back to sell at a lower price in cash. The Contract like this is Hillah (legal fiction) of fall on usury, and in fact the contract is not a sale and purchase agreement in the transaction.

Likewise buying and selling by using two prices. Sale and purchase is prohibited when a contract containing two transactions, one of the selling was declared valid and binding (common) before the parties separated but not specified which of purchase was valid and binding. The cause of the ban on sale and purchase forms are uncertainties (gharar) arising from obscurity value priced (jahā lah). (Riyadi, 2014: 252) 
The majority of jurists agree that in general "the two sale and purchase in one trade" is not justified (forbidden) by Islamic law. scholars interpret "the seller told the buyer:" I sell this shirt for ten dirhams in cash or twenty dirhams are not cash the payment period for a year. "Then the buyer accept or approve it without specifying one of the two that price." Exegesis so followed by Malik, Abu Hanifah, al-Thawri, Ishaq, al-Shafi'i in one of two opinions, and other scholars. But they differed as to the cause of law ('illah) from the ban According to al-Shafi'i and Abu Hanifah, "his illat is vagueness price.

Thus, according to two of these scholars, the form of buying and selling are included in the category of "bay' al-gharar" that is also prohibited. Meanwhile, according to Malik, 'illah is closed off to deliver on the usury. That it may be that the parties have the right to choose / khiyā $r$ (generally the buyer) initially has chosen to carry out the contract with one price (e.g. a cash price that is cheaper), and then replace it by choosing the price of both. This means he has let one price to obtain a second price; and it is seen as having sold one price with the price action as it was the same as the sales activities of a price (thaman, in this case money) with other prices are not cash and it is usury nasai 'or even usury Faḍl.

Fund raising activities, especially funds derived from the public carried out by Islamic banks refers to Law 21 of 2008 in Article 1 (1) a and b are in the form of savings or investments. Savings can be a checking, savings, or other equivalent form with it based on the waḍia principles. As for the investment in the form deposits, savings or other forms equated with it based mudā raba. Both the savings and the investment is made possible using the contract other than waḍi $\mathfrak{i}$ and mudā raba with other contract terms were not contrary to Islamic principles. (Hakim, 2011: 203)

\section{Giro Multiple Contract}

The word "contract" in Indonesian means agreement. The word ("'aqd") comes from the Arabic meaning bind, define, build, and opponents of the release. The word covenant means also the engagement or appointment. (Manan, 2012: 72). The words have been absorbed in Indonesian which means promises, agreements, and contracts. "'Aqd" is the agreement of both parties who require both implement what has been agreed. (Anwar, 2010: 68). Wahbah Al-Zuhaili explained that the contract is binding between the tip of something, either a bond is real and the abstract (meaningful), from one parties and two parties. (Al-Zuhayly 2006: 2917). From this sense it is understood that the contract is the agreement activities of the two parties for a specific purpose that result in the emergence legal consequences that must be met by both parties mutually binding, and gave birth to a legal purpose to be realized. Meanwhile, according to the terms of jurisprudence, the word "multiple contract" is a translation of the Arabic word al-'uqu $d$ al-murakkaba which means the contract is doubled (Hasanuddin, 2008: 50).

More broadly, multiple contract can be defined as an agreement between the two parties to implement a contract containing two contract or more so that all the legal consequences of the contract that is collected, as well as all rights and obligations thereof viewed as a single entity that cannot be separated, as a result of law of the contract. Therefore, in multiple contract, the contract being gathered two or more it is also known by the principal contract and the contract asesoir. Principal contract is the core of the contract which will be executed while asesoir contract is an agreement to carry out additional principal contract so that the contract depends on the subject matter of the contract asesoir. If the asesoir contract is not implemented, then the principal contract becomes invalid. (Hasanuddin, 2008: 51). 
The Giro is one of banking products in the field of funding from society. Demand deposits are deposits which may be withdrawn at any time by the user checks, giro, forms of payment order or by transfer. (Law of the Republic of Indonesia Number 10 of 1998). According to Taufik Hidayat, the Giro is a deposit of funds which may be withdrawn at any time by the user checks, giro, forms of payment order or by transfer. (Hidayat, 2011: 133) Giro same termed by Adiwarman karim, the savings can be done at any time by check, giro, and other payment means, or by transfer. (Karim, 2004: 291). From this sense it is understood that the gyro is one product in funding from Islamic banking; giro use waḍ̂ $\vec{a}$ contract in deposits and storage can be pulled at any time by way of the existing.

\section{Collection of funds}

Raising funds in Islamic banks can take the form of demand deposits, savings and time deposits. The operational principle of sharia applied in public fund raising is the principle Waḍia and Mựā raba. (Karim, 2004: 170).

a. Giro there are two types (NSC-ICU Fatwa No: 01/DSN-MUI/IV/2000): The Giro is not justified by Sharia, namely current accounts based on the calculation of interest.

b. The Giro is justified by Sharia, which is based on the principle Waḍ̂'a demand deposits and Muḍā raba.

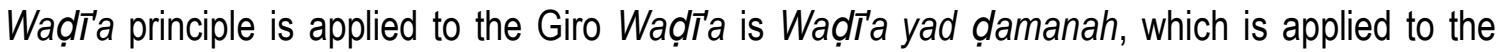
checking account product. Waḍ̂̉a yad ḍamanah is different from Waḍīa yad amā nah. In Waḍ̂̄a yad amā nah, in principle, entrusted property may not be used by the entrusted. Meanwhile, in the case of wadi'ah dhamanah, entrusted party (bank) is responsible for the property needs a deposit so he can take advantage of the deposit treasure. Because Waḍi a applied in this bank giro products also are yad damanah, together with qardh legal implications, in which the customer acts as the offers of money, and the bank acts as the lent. So, similar to those of Zubayr ibn al-Awam when it receives deposits of money at the time of the Prophet Muhammad. (Karim, 2004: 108).

In general, Islamic banks use futures' contract Waḍīa yad damanah to a checking account. (Antono, 2001: 37) Due to its nature is a deposit which can be taken at any time, then checking with wadi'ah principle should not give advantages to customers. Bank reserves the right to manage the funds deposited by customers for commercial activity with a fixed nominal must guarantee repayment of these funds even so, the banks do not give bonuses or hadiyah as long as long as not promised in advance. (Hidayat, 2011: 135) and based on NSC-ICU Fatwa NO; 01 / DSN-MUI / IV / 2000: (1) merely deposited; (2) Courier can be taken at any time (on call); and (3) No remuneration that is required, except through the provision ('Athaya) that is voluntary on the part of banks.

While in the mean by giro muḍa raba, he was checking on the run by mudā raba. Muḍā raba has two forms, namely: (1) muḍā raba muțlaqa is the owner does not give any requirement, give free.; and (2) muḍā raba muqayyadah is șā hib al-mā I (the owner of the fund) fund to give banks the requirement to manage his money, both in terms of place, time, and object of investment.

Islamic Bank acting as șā hib al-mā I (the owner of the funds). Islamic banks can perform a wide variety of businesses that are not contrary to Islamic principles, and develop it, including doing muḍa raba with other parties. Thus, Islamic banks in their capacity as muḍa rib has properties as a trustee, which must be careful or prudent and good will and is responsible for all things arising from fault or 
negligence. In addition, Islamic banks also act as the power of the business owners of the funds that is expected to benefit optimally as possible without violating the rules of sharia.

From the results of muḍa raba fund management, Islamic banks will divide the produce to the owner of the funds in accordance with the ratio agreed and stipulated in the contract of account opening. In managing the Fund, the bank is not responsible for any damages that are not caused by negligence. However, if that is happens is mismanagement, bank fully responsible for such losses. In managing the assets of mudā raba, a bank giro cover operational costs by using the ratio of profit which they are entitled. In addition, banks are not allowed to reduce the ratio of financial accountholding without that person's consent. In accordance with applicable regulations, income tax revenue sharing muḍā raba charged directly to the account-giro muḍa raba when the accounts for the results. Giro mudā raba calculation for results is based on the average daily balance that is calculated at the end of every month and at the beginning of the next month book. (Karim, 2004: 108)

General provisions Giro muḍā raba (NSC-ICU Fatwa No: 01 / DSN-MUI / IV / 2000): (1) In this transaction, the customer acts as șā hib al-mā I or the owner of the funds, and the bank acts as muḍā rib or fund manager; (2) In his capacity as muḍā rib, banks can perform a wide variety of businesses that do not conflict with the principles of Shariah and develop it, including mudā raba with other parties; (3) Capital should be stated with the amount, in the form of cash and not receivable; (4) Distribution of profits must be expressed in the form of a ratio and set forth in the contract of account opening; (5) Bank as muḍā rib, cover operational giro costs by using profits ratio which they are entitled; and (6) The Bank is not allowed to reduce the ratio of clients profit without their consent.

\section{CONCLUSION}

The contract is a contract single stand-alone and has its own legal consequences. This contract is mostly done in general to the apostolic thus not widely found shapes that is merge two contract transactions. However, there are some traditions that prohibit the merger of the two transactions in particular. With today's development, the existence of multiple contract indispensable to support Islamic financial institutions in issuing products. Multiple contract is some combination of both gathered contract or on parole that is have legal effect be one that is the legal effect of a combination of such contract. There are two opinions regarding the multiple contract law. The majority of scholars state that the law valid and allowed it. The merger ban is only applicable to sale and purchase agreement. 'Illah of the ban is the lack of clarity of prices will lead to uncertainty (gharar) due to avoid riba' (usury Hīlah). So in Islam every multiple contract cause prices obscurity and uncertainty and Hillah to avoid usury is a multi-contract prohibited and NSC-ICU issued a fatwā regarding it. 


\section{References}

Al-'Imrani, Abdullâh. (2010), Al-'Uqū d al-Mā liyah al-Murakkabah, Riyadh : Dar al-Kunuz Isbiliyah.

Al-Tahanawi. (n.d.) Kashshā f Ishthilā ḥā t al-Funū n, Beirut: Dâr Shâdir.

Antono, Muhammad Syafi'i. (2001). Bank Syariah, Jakarta: Gema Insani Press.

Anwar, Syamsul. (2010). Hukum Perjanjian Syariah, Jakarta: Rajawali Pers

Fatwa Dewan Syari'ah Nasional NO; 01 / DSN-MUI / IV / 2000.

Hakim, Atang Abd.. (2011). Fiqih Perbankan Syariah, Bandung: PT Refika Aditama.

Hanbal, Ahmad bin, (1414 H) Musnad Ahmad, V. 2, Beirut: Dar al-Ihya' al-Turats al-'Araby,

Hasanudin. (2008). Konsep dan Standar Multi Akad dalam Fatwa DSN-MUI, Desertasi UIN Syarif Hidayatullah Jakarta.

Hidayat, Taufik. (2011). Buku Pintar Investasi Syariah, Jakarta: Mediakita.

Al-Humam, Kamaluddin M. Ibn. (1356/1937). Fath al-Qadir, Mısr.

Ichwan, Sam et. Al. (2014). Himpunan Fatwa Keuangan Syariah DSN-MUI, Jakarta: Erlangga.

Ikatan Bankir Indonesia. (2014). Memahami Bisnis Bank Syariah, Jakarta: Gramedia Pustaka Utama.

Meftah, Jilani Ben Touhami. (2013). "Fractional Banking System with the Unknown Risk", International Journal of Nusantara Islam, Vol. 1, (2), pp. https://dx.doi.org/10.15575/ijni.v1i2.31

Karim, Adiwarman A. (2004). Bank Islam Analisis Fiqh dan Keuangan, Edisi Ill. Jakarta: Raja Grafido Persada.

Mahmashani, Subhi .(1961). Falsafat Al-Tashrī’ fĩ al-Islā m, Beirut: Dar al-'Ilm li al-Malayin.

Mannan, Abdul. (2012). Hukum Ekonomi Syariah, Jakarta: Kencana.

Praja, Juhaya S. (2012). Ekonomi Syariah, Bandung: Pustaka Setia.

Riyadi, Abdul Kadir. (2014). Prinsip Dasar Ekonomi Islam Persfektif Maqashid Syariah, Jakarta: Kencana.

Sjahdeni, Sutan Remy. (2014). Perbankan Syariah, Jakarta: Kencana.

Al-Zuhaily, Wahbah. (2006). Al-Fiqh al-Islāmī wa Adillatuh, Juz. 4, Syiria: Dar al-Fikr. 